\title{
Lithium-Acetate-Mediated Biginelli One-Pot Multicomponent Synthesis under Solvent-Free Conditions and Cytotoxic Activity against the Human Lung Cancer Cell Line A549 and Breast Cancer Cell Line MCF7
}

\author{
Harshita Sachdeva and Diksha Dwivedi \\ Department of Chemistry, Faculty of Engineering and Technology, Mody Institute of Technology and Science, \\ Lakshmangarh 332311, Rajasthan, India \\ Correspondence should be addressed to Harshita Sachdeva, drhmsachdevaster@gmail.com
}

Received 12 October 2011; Accepted 22 November 2011

Academic Editor: Robert Zakrzewski

Copyright ( 92012 H. Sachdeva and D. Dwivedi. This is an open access article distributed under the Creative Commons Attribution License, which permits unrestricted use, distribution, and reproduction in any medium, provided the original work is properly cited.

\begin{abstract}
Various Biginelli compounds (dihydropyrimidinones) have been synthesized efficiently and in high yields under mild, solventfree, and eco-friendly conditions in a one-pot reaction of 1,3-dicarbonyl compounds, aldehydes, and urea/thiourea/acetyl thiourea using lithium-acetate as a novel catalyst without the addition of any proton source. Comparative catalytic efficiency of lithiumacetate and polyphosphoric acid to catalyze Biginelli condensation is also studied under neat conditions. The reaction is carried out in the absence of any solvent and represents an improvement of the classical Biginelli protocol and an advantage in comparison with $\mathrm{FeCl}_{3} \cdot 6 \mathrm{H}_{2} \mathrm{O}, \mathrm{NiCl}_{2} \cdot 6 \mathrm{H}_{2} \mathrm{O}$ and $\mathrm{CoCl}_{2} \cdot 6 \mathrm{H}_{2} \mathrm{O}$ that were used with $\mathrm{HCl}$ as a cocatalyst. Compared to classical Biginelli reaction conditions, the present method has advantages of good yields, short reaction times, and experimental simplicity. The obtained products have been identified by spectral ( ${ }^{1} \mathrm{H}$ NMR and IR) data and their melting points. The prepared compounds are evaluated for anticancer activity against two human cancer cell lines (lung cancer cell line A549 and breast cancer cell line MCF7).
\end{abstract}

\section{Introduction}

Multicomponent reactions (MCRs) have emerged as an efficient and powerful tool in modern synthetic organic chemistry because the synthesis of complex organic molecules from simple and readily available substrates can be achieved in a very fast and efficient manner without the isolation of any intermediate $[1,2]$. Therefore, the discovery for new MCRs and improving the already-known MCRs are of considerable interest. Perusal of literature revealed that the Biginelli reaction, which was discovered more than a century ago, is one of the most important MCRs for the synthesis of dihydropyrimidinones based on acid-catalyzed three component condensation of $\beta$-dicarbonyl compound, an aldehyde, and urea or thiourea $[3,4]$.

The development of new strategies for the preparation of complex molecules in neat conditions is a challenging area of organic synthesis. The pioneering work of Toda et al. [5] has shown that many exothermic reactions can be accomplished in high yield by just grinding solids together using mortar and pestle, a technique known as "grindstone chemistry," which is one of the "green chemistry techniques." Reactions are initiated by grinding, with the transfer of very small amounts of energy through friction [6]. In addition to being energy efficient, grindstone chemistry also results in high reactivity and less waste products. Such reactions are simple to handle, reduce pollution, comparatively cheaper to operate, and may be regarded as more economical and ecologically favorable procedure in chemistry [7]. Generally, solid-state reactions occur more efficiently and more selectively than does the solution reaction, since molecules in the crystals are arranged tightly and regularly [8].

The classical Biginelli reactions were conducted under strongly acidic conditions, which suffer from poor yields, and 
long reaction time and sensitive functional groups are lost during the reaction conditions. This has lead to the development of several new methodologies, which improve the yields compared to original procedure. These new strategies involve the combinations of Lewis acids and/or transition metal salts, for example, $\mathrm{BF}_{3} \cdot \mathrm{OEt}_{2}$, montmorillonite (KSF), polyphosphate esters, and reagents like $\mathrm{InCl}_{3}$ [9], $\mathrm{LiBr}$ [10], TMSCl/NaI [11], $\mathrm{LaCl}_{3} \cdot 7 \mathrm{H}_{2} \mathrm{O}$ [12], $\mathrm{CeCl}_{3} \cdot 7 \mathrm{H}_{2} \mathrm{O}$ [13], $\mathrm{Mn}(\mathrm{OAc})_{3} \cdot 2 \mathrm{H}_{2} \mathrm{O}$ [14], $\mathrm{InBr}$ [15], $\mathrm{FeCl}_{3}$ and $\mathrm{HCl}$ [16], ytterbium triflate [17], Iodine [18], $\mathrm{ZnCl}_{2}$ [19], $\mathrm{CoCl}_{2}$ [20], and so forth. Many Lewis acids and transition metal salts have been found to catalyze this reaction, but they still have limitations like high cost, limited availability, prolonged reaction duration, and the use of strong acids. The combination of solvents and long reaction time, costly chemicals/catalysts, makes this method environmentally hazardous. Therefore, development of simple, efficient, clean, high yielding, and environmentally friendly approaches using new catalysts for the synthesis of these compounds is an important task of organic chemists.

Although the original Biginelli protocol of acid-catalyzed condensation in ethanol is effective method but still various modifications of solvents and catalyst are the subject of this synthesis. During our quest to develop novel catalysts for multicomponent reactions, we have found that lithiumacetate is effective promoter of Biginelli reaction. Literature survey revealed that so far some metal acetates [21] seem to have been utilized to catalyze Biginelli reactions in the presence of solvents but lithium-acetate has not been utilized so far.

As per our ongoing efforts to synthesize privileged class of compounds $[22,23]$ and our interest in Lewis acid applications for the Biginelli reaction, herein we wish to report for the first time a novel, simple, and efficient methodology for the synthesis of 3, 4-dihydropyrimidin-2(1H)ones and thiones (DHPMs) by the reaction of aldehydes, 1,3dicarbonyl compounds, and urea/thiourea using catalytic amount of lithium-acetate and (polyphosphoric acid) PPA under solvent-free conditions (Scheme 1). Further, comparative catalytic efficiency of lithium-acetate and PPA to catalyze Biginelli condensation is also studied under neat conditions.

\section{Results and Discussion}

The current method not only preserves the "one-pot" protocol of Biginelli condensation but also favors environmentally benign reaction conditions of saving energy consumption. Literature survey revealed that there is little report [24] on its use in the synthesis of DHPMs and this technique is superior to the existing methods, since grinding does not require solvents leading to safe and environmental friendly synthesis. Furthermore, the proposed technique does not require external heating or cooling at any stage, leading to energy efficient synthesis providing high yields of products.

In order to optimize the reaction conditions, the synthesis of compound 1 was used as a model reaction and a mixture of benzaldehyde, ethylacetoacetate, and urea in the presence of lithium-acetate/PPA was magnetically stirred at room temperature in different solvents (Table 1).
The best yield (73\%) was obtained when 0.5 equivalents of lithium-acetate/PPA (entries 3 and 6), 1 equivalents of both benzaldehyde and ethylacetoacetate, and 2 equivalents of urea were magnetically stirred in acetonitrile $\left(\mathrm{CH}_{3} \mathrm{CN}\right) /$ Tetrahydrofuran (THF), respectively, for 7-8 hours.

It seems that THF is a much better solvent in PPA catalyzed reaction (entry 3 ) whereas $\mathrm{CH}_{3} \mathrm{CN}$ is better in lithium-acetate-promoted reaction in terms of yields and time than all other tested solvents (entry 6). However, under solvent-free conditions reaction was fast and $90-95 \%$ yield of DHPMs was obtained in 10-15 minutes (Table 2).

Encouraged by these results, and due to increasing demand in modern organic processes of avoiding expensive purification techniques and large amount of solvents, we examined the reactivity of our catalysts under solventfree conditions. The three component cyclocondensation reaction was carried out either by stirring a mixture of aromatic aldehyde (1 eq.), 1,3-dicarbonyl compounds (1 eq.), urea/thiourea/acetyl thiourea (2 eq.), and catalytic amount of lithium-acetate/PPA (0.5 eq.) for 30-35 minutes at 70$80^{\circ} \mathrm{C}$ temperature (Method I) or by grinding the reactants together for 5-10 minutes at room temperature (Method II). After the completion of reaction (as monitored by TLC), the reaction mixture was cooled to room temperature and poured onto crushed ice, filtered, and recrystallized by using either ethanol or ethyl acetate and pet ether $(1: 1)$ to afford pure product. As reaction was carried out under solvent-free conditions, clean products are obtained. It has been observed that yield obtained by Method I is $10-15 \%$ better than that obtained in case of Method II.

With the aim of improving the reaction yields, we attempted to add different equivalents of catalyst to the reaction mixture and the best condition to prepare DHPMs was achieved when reaction was carried out in the presence of 0.5 eq. of catalyst. The use of large amount of catalyst ( $1 \mathrm{eq}, 1.5$ eq., or 2 eq.) does not increase the yields. To check promoter efficiency of catalyst and reproducibility of the reaction, different aldehydes were reacted with urea/thiourea/acetyl thiourea to give 27 different compounds. It was found that catalysts employed (PPA/Lithium-acetate) differed in their efficiency in terms of yields and purity.

In all cases studied, the three-component reaction proceeded smoothly to give the corresponding DHPMs (1-27) in satisfactory yields. Most importantly, aromatic aldehydes carrying either electron-donating or electron-withdrawing substituents reacted very well to give the corresponding DHPMs with high purity in moderate-to-good yields. Another important feature of this procedure is the tolerance of various functional groups, such as methoxy, halides, and hydroxy, to the reaction conditions. Thiourea/acetyl thiourea (entries 2, 8, 13, 15, 19, and 24-27) has been used with similar success to provide corresponding S-dihydropyrimidinone analogues, which are also of interest due to their biological activities. It should be noted that PPA or lithium-acetate was used as the sole promoter agent in neutral media and reaction proceeded without using any additional proton source while for others previously reported $[16,20]$ hydrates of metal halides such as Fe (III), Ni (II), and Co (II), a 


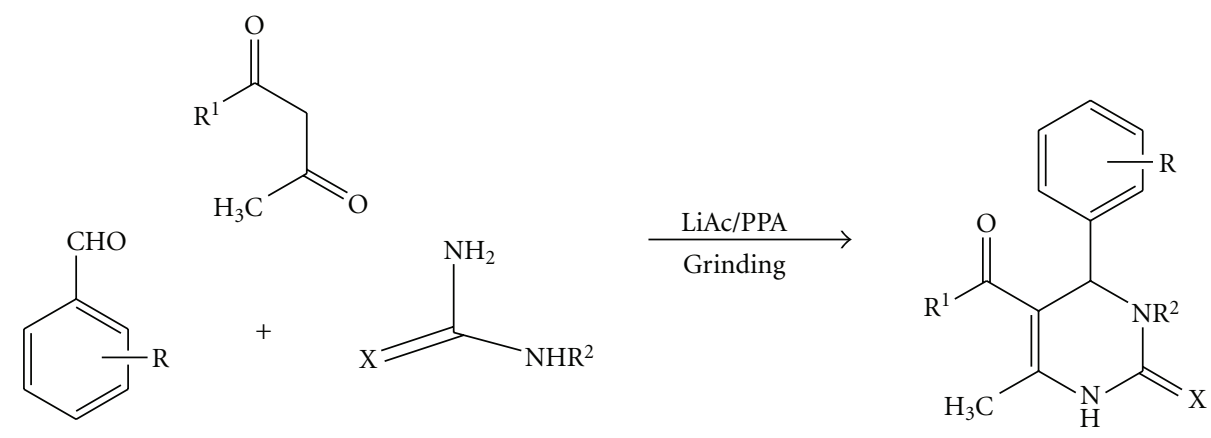

Scheme 1

TABle 1: Synthesis of Compound 1 at room temperature in the presence of PPA and Lithium-acetate in different solvents. ${ }^{a}$

\begin{tabular}{lcccc}
\hline Entry & Solvent & Catalyst & Time (hrs) & Yield (\%) \\
\hline 1 & EtOH & PPA & 4 & 67 \\
2 & $\mathrm{CH}_{3} \mathrm{CN}$ & PPA & 5 & 58 \\
3 & THF & PPA & 2 & 73 \\
4 & Toluene & PPA & 8 & 48 \\
5 & EtOH & Lithium-Acetate & 4 & 63 \\
6 & $\mathrm{CH}_{3} \mathrm{CN}$ & Lithium-Acetate & 3 & 73 \\
7 & THF & Lithium-Acetate & 6 & 68 \\
8 & Toluene & Lithium-Acetate & 7 & 43 \\
\hline
\end{tabular}

${ }^{\mathrm{a}}$ The reactions were carried out in the presence of benzaldehyde $(1.0 \mathrm{mmol})$, ethyl acetoacetate $(1.0 \mathrm{mmol})$, urea $(2.0 \mathrm{mmol})$, and PPA or lithium-acetate $(0.5 \mathrm{mmol})$ at room temperature for 6-7 hrs.

catalytic amount of conc. $\mathrm{HCl}$ was needed as a Bronsted acid cocatalyst. Melting points of most of synthesized DHPMs were found to be much closer to reported DHPMs indicating high purity of the compounds (Table 2). The structure of all the dihydropyrimidinones prepared is characterized by IR and ${ }^{1} \mathrm{H}$ NMR and are well correlated with the available literature data.

2.1. Evaluation of Anticancer Activity. The synthesized compounds 6, 16, 18, 23, 24 were evaluated [31] for anticancer activity against human lung cancer cell line A549 and 2, 3, 7, 12, 22 against human breast cancer cell line MCF7. The cell lines were grown in RPMI 1640 medium containing $10 \%$ fetal bovine serum and $2 \mathrm{mM} \mathrm{L}$-glutamine. For present screening experiment, cells were inoculated into 96 well microtiter plates in $90 \mu \mathrm{L}$ at plating densities, depending on the doubling time of individual cell lines. After cell inoculation, the microtiter plates were incubated at $37^{\circ} \mathrm{C}$, $5 \% \mathrm{CO}_{2}, 95 \%$ air, and $100 \%$ relative humidity for $24 \mathrm{~h}$ prior to addition of experimental drugs. After $24 \mathrm{~h}$, one plate of each cell line was fixed in situ with TCA, to represent a measurement of the cell population for each cell line at the time of drug addition $(T z)$. Experimental drugs were solubilized in appropriate solvent at 400 -fold the desired final maximum test concentration and stored frozen prior to use. At the time of drug addition, an aliquot of frozen concentrate was thawed and diluted to 10 times the desired final maximum test concentration with complete medium containing test article at a concentration of $10^{-3}$. Additional three, 10-fold serial dilutions were made to provide a total of four drug concentrations plus control. Aliquots of $10 \mu \mathrm{L}$ of these different drug dilutions were added to the appropriate microtiter wells already containing $90 \mu \mathrm{L}$ of medium, resulting in the required final drug concentrations.

2.2. Endpoint Measurement. After compound addition, plates were incubated at standard conditions for 48 hours and assay was terminated by the addition of cold TCA. Cells were fixed in situ by the gentle addition of $50 \mu \mathrm{L}$ of cold $30 \%$ $(\mathrm{w} / \mathrm{v})$ TCA (final concentration, 10\% TCA) and incubated for 60 minutes at $4^{\circ} \mathrm{C}$. The supernatant was discarded; the plates were washed five times with tap water and airdried. Sulforhodamine B (SRB) solution $(50 \mu \mathrm{L})$ at $0.4 \%(\mathrm{w} / \mathrm{v})$ in $1 \%$ acetic acid was added to each of the wells, and plates were incubated for 20 minutes at room temperature. After staining, unbound dye was recovered and the residual dye was removed by washing five times with $1 \%$ acetic acid. The plates were air-dried. Bound stain was subsequently eluted with $10 \mathrm{mM}$ trizma base, and the absorbance was read on an ELISA plate reader at a wavelength of $540 \mathrm{~nm}$ with $690 \mathrm{~nm}$ reference wavelengths. Percent growth was calculated on a plate-by-plate basis for test wells relative to control wells.

Percent Growth was expressed as the ratio of average absorbance of the test well to the average absorbance of the control wells $* 100$.

Using the six-absorbance measurements time zero $(\mathrm{Tz})$, control growth $(C)$, and test growth in the presence of drug at the four concentration levels $(T i)$, the percentage growth was calculated at each of the drug concentration levels.

Percentage growth inhibition was calculated as

$$
\begin{aligned}
& {\left[\frac{(T i-T z)}{(C-T z)}\right] \times 100 \text { for concentrations for which } T i} \\
& \quad \geq T z(T i-T z) \text { positive or zero, } \\
& {\left[\frac{(T i-T z)}{T z}\right] \times 100 \text { for concentrations for which } T i} \\
& \quad<T z .(T i-T z) \text { negative. }
\end{aligned}
$$

The dose response parameters were calculated for each test article. Growth inhibition of 50\% (GI50) was calculated 
TABLE 2: Physical characterization data of compounds. ${ }^{\mathrm{a}}$

\begin{tabular}{|c|c|c|c|c|c|c|c|c|}
\hline \multirow{2}{*}{ Compound } & \multirow{2}{*}{$\mathrm{R}$} & \multirow{2}{*}{$\mathrm{R}^{1}$} & \multirow{2}{*}{$\mathrm{R}^{2}$} & \multirow{2}{*}{$\mathrm{X}$} & \multirow{2}{*}{ PPA Yield (\%) } & \multirow{2}{*}{ LiAc Yield (\%) } & \multicolumn{2}{|c|}{ M.P. $\left({ }^{\circ} \mathrm{C}\right)$} \\
\hline & & & & & & & Found & Reported \\
\hline 1 & $\mathrm{H}$ & OEt & $\mathrm{H}$ & $\mathrm{O}$ & 94 & 90 & $198-202$ & $202-203[25]$ \\
\hline 2 & $\mathrm{H}$ & OEt & $\mathrm{H}$ & S & 88 & 85 & $202-204$ & $204-206$ [25] \\
\hline 3 & $4-\mathrm{OCH}_{3}$ & OEt & $\mathrm{H}$ & $\mathrm{O}$ & 93 & 91 & $205-207$ & $199-200[25]$ \\
\hline 4 & 4-OH & OEt & $\mathrm{H}$ & $\mathrm{O}$ & 87 & 82 & $224-226$ & $232-234$ [25] \\
\hline 5 & $2-\mathrm{OH}$ & OEt & $\mathrm{H}$ & $\mathrm{O}$ & 85 & 80 & $195-200$ & $201-203$ [25] \\
\hline 6 & $3-\mathrm{OH}$ & OEt & $\mathrm{H}$ & $\mathrm{O}$ & 78 & 81 & $161-163$ & $163-165$ [26] \\
\hline 7 & $4-\mathrm{Cl}$ & OEt & $\mathrm{H}$ & $\mathrm{O}$ & 92 & 89 & 205-208 & $212-213$ [25] \\
\hline 8 & $4-\mathrm{Cl}$ & OEt & $\mathrm{H}$ & S & 88 & 80 & $208-210$ & $176-177$ [27] \\
\hline 9 & $3-\mathrm{Cl}$ & OEt & $\mathrm{H}$ & $\mathrm{O}$ & 74 & 72 & $185-187$ & $190-192$ [12] \\
\hline 10 & $2-\mathrm{Cl}$ & OEt & $\mathrm{H}$ & $\mathrm{O}$ & 78 & 77 & 190-192 & $220-222[26]$ \\
\hline 11 & $2-\mathrm{Cl}$ & $\mathrm{OMe}$ & $\mathrm{H}$ & $\mathrm{O}$ & 80 & 82 & $245-248$ & $252-253[28]$ \\
\hline 12 & $3-\mathrm{OCH}_{3}$ & OEt & $\mathrm{H}$ & $\mathrm{O}$ & 92 & 87 & $210-212$ & $220-221[29]$ \\
\hline 13 & $3-\mathrm{OCH}_{3}$ & OEt & $\mathrm{H}$ & S & 88 & 84 & $214-216$ & - \\
\hline 14 & 2,4-Dimethyl & OEt & $\mathrm{H}$ & $\mathrm{O}$ & 82 & 85 & 200-202 & - \\
\hline 15 & 3,4-dimethyl & OEt & $\mathrm{H}$ & $\mathrm{S}$ & 77 & 78 & $203-205$ & - \\
\hline 16 & $3-\mathrm{OH}, 4-\mathrm{OCH}_{3}$ & OEt & $\mathrm{H}$ & $\mathrm{O}$ & 84 & 81 & $225-227$ & $230-232[30]$ \\
\hline 17 & $3-\mathrm{OCH}_{3}, 4-\mathrm{OH}$ & OEt & $\mathrm{H}$ & $\mathrm{O}$ & 88 & 83 & $230-232$ & $233-235$ [30] \\
\hline 18 & 3,4,5- Trimethoxy & OEt & $\mathrm{H}$ & $\mathrm{O}$ & 92 & 88 & $202-205$ & $216-218[24]$ \\
\hline 19 & 3,4,5- Trimethoxy & $\mathrm{OMe}$ & $\mathrm{H}$ & $\mathrm{S}$ & 84 & 78 & $187-190$ & - \\
\hline 20 & 3,4,5- Trimethoxy & $\mathrm{OMe}$ & $\mathrm{H}$ & $\mathrm{O}$ & 87 & 84 & 190-192 & - \\
\hline 21 & $4-\mathrm{F}$ & OEt & $\mathrm{H}$ & $\mathrm{O}$ & 91 & 80 & $189-192$ & $192-194[24]$ \\
\hline 22 & $4-\mathrm{CF}_{3}$ & OEt & $\mathrm{H}$ & $\mathrm{O}$ & 88 & 83 & $165-167$ & - \\
\hline 23 & $2-\mathrm{CF}_{3}$ & OEt & $\mathrm{H}$ & $\mathrm{O}$ & 90 & 87 & $174-176$ & - \\
\hline 24 & $3-\mathrm{OH}, 4-\mathrm{OCH}_{3}$ & $\mathrm{CN}$ & $\mathrm{COCH}_{3}$ & $\mathrm{~S}$ & 89 & 88 & $210-212$ & - \\
\hline 25 & $3-\mathrm{OCH}_{3}, 4-\mathrm{OH}$ & $\mathrm{CN}$ & $\mathrm{COCH}_{3}$ & S & 84 & 87 & 190-195 & - \\
\hline 26 & $4-\mathrm{OH}$ & $\mathrm{CN}$ & $\mathrm{COCH}_{3}$ & $S$ & 92 & 88 & $186-190$ & - \\
\hline 27 & $4-\mathrm{Cl}$ & $\mathrm{CN}$ & $\mathrm{COCH}_{3}$ & $\mathrm{~S}$ & 90 & 87 & 196-198 & 一 \\
\hline
\end{tabular}

${ }^{\mathrm{a}}$ The reactions were carried out by grinding aromatic aldehyde $(1.0 \mathrm{mmol}), 1,3$-dicarbonyl compounds $(1.0 \mathrm{mmol})$, urea/thiourea/acetyl thiourea $(2.0 \mathrm{mmol})$, and PPA or lithium-acetate $(0.5 \mathrm{mmol})$ in mortar and pestle at room temperature for 5-10 minutes (Method II).

from $[(T i-T z) /(C-T z)] \times 100=50$, which is the drug concentration resulting in a $50 \%$ reduction in the net protein increase (as measured by SRB staining) in control cells during the drug incubation. The drug concentration resulting in total growth inhibition (TGI) was calculated from $T i=T z$. The LC50 (concentration of drug resulting in a $50 \%$ reduction in the measured protein at the end of the drug treatment as compared to that at the beginning) indicating a net loss of cells following treatment is calculated from

$$
\left[\frac{(T i-T z)}{T z}\right] \times 100=-50
$$

Values were calculated for each of these three parameters if the level of activity was reached; however, if the effect was not reached or was exceeded, the values for that parameter were expressed as greater or less than the maximum or minimum concentration tested.

The data of anticancer activity in terms of \% control growth at different molar drug concentration are shown in Tables 3 and 4. Unfortunately, all the evaluated compounds showed poor activity against human cancer cell lines. Growth curves are presented in Figure 1.

Definitions. LC50: concentration of drug causing 50\% cell kill; GI50: concentration of drug causing 50\% inhibition of cell growth; TGI: concentration of drug causing total inhibition of cell growth; ADR: adriamycin, positive control compound. GI50 value of $\leq 10^{-6}$ molar (i.e., $1 \mu$ molar) or $\leq 10 \mu \mathrm{g} / \mathrm{mL}$ is considered to demonstrate activity in case of pure compounds. For extracts, GI50 value $\leq 20 \mu \mathrm{g} / \mathrm{mL}$ is considered to demonstrate activity Italic test values under GI50 column indicate activity in Table 4.

\section{Conclusions}

This method offers a simple, inexpensive, versatile, and environment friendly approach to the synthesis of a library of DHPMs. Lithium-acetate acts as an efficient promoter system of the Biginelli reaction yielding DHPMs in good-toexcellent yields. Comparative promoter efficiency of lithiumacetate and PPA to catalyze Biginelli condensation reaction is also studied under neat conditions and it has been found that 


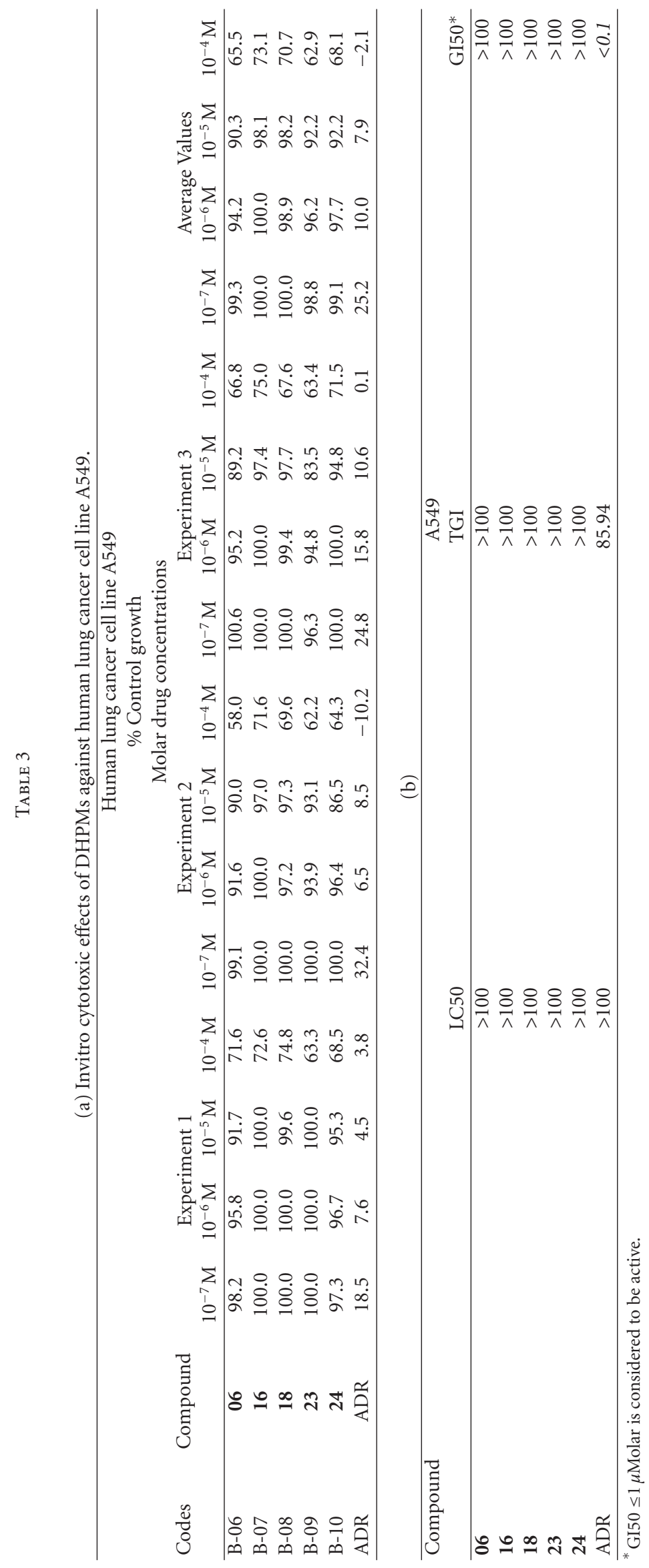




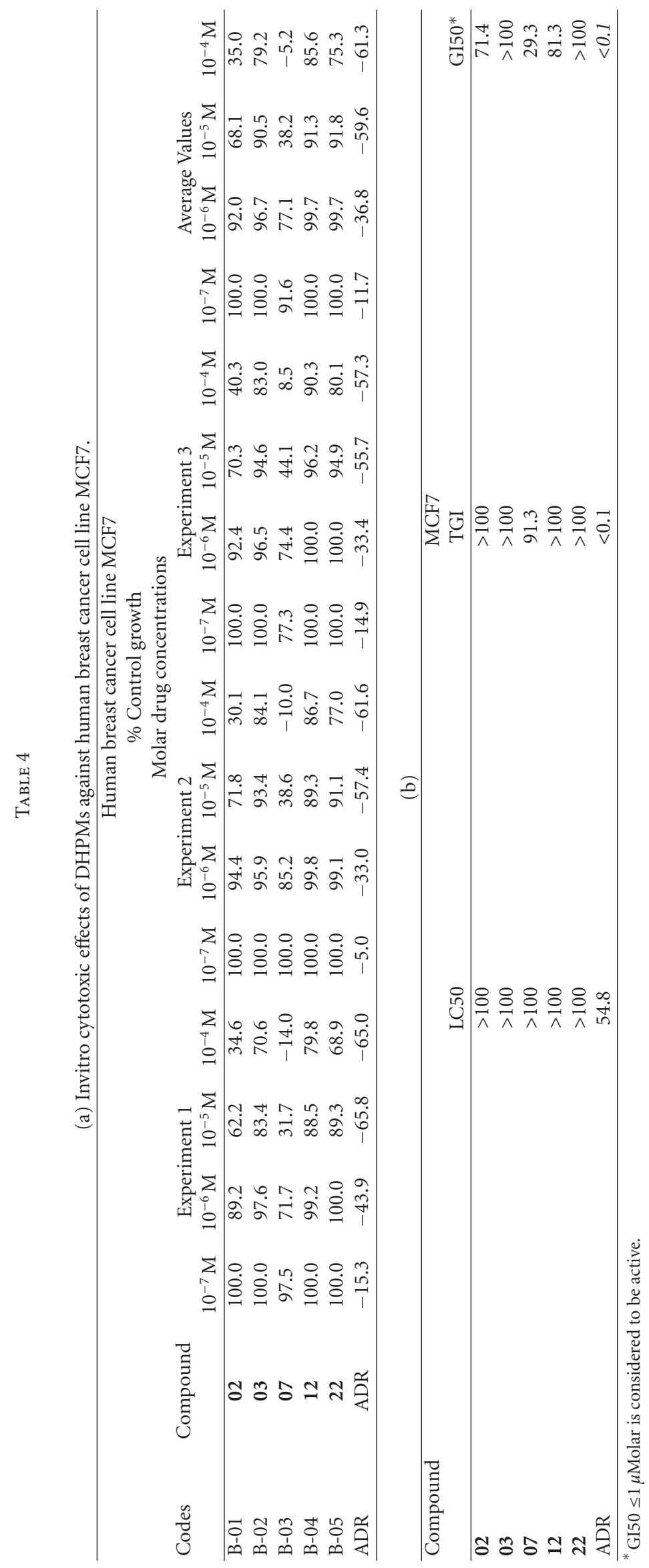




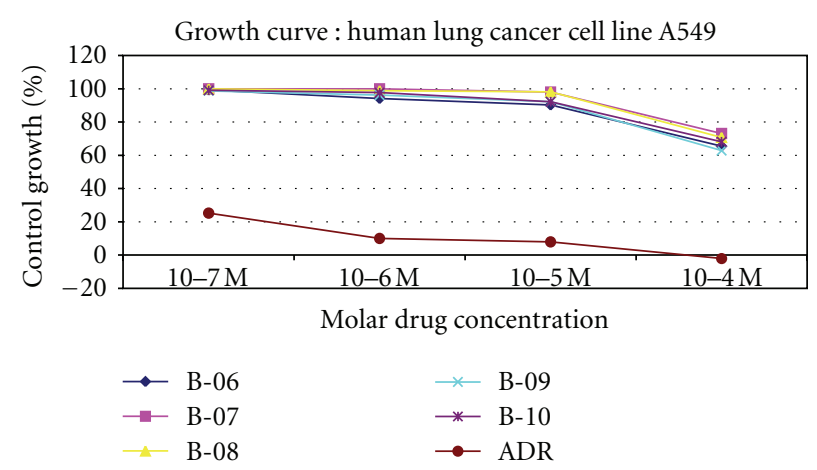

(a)

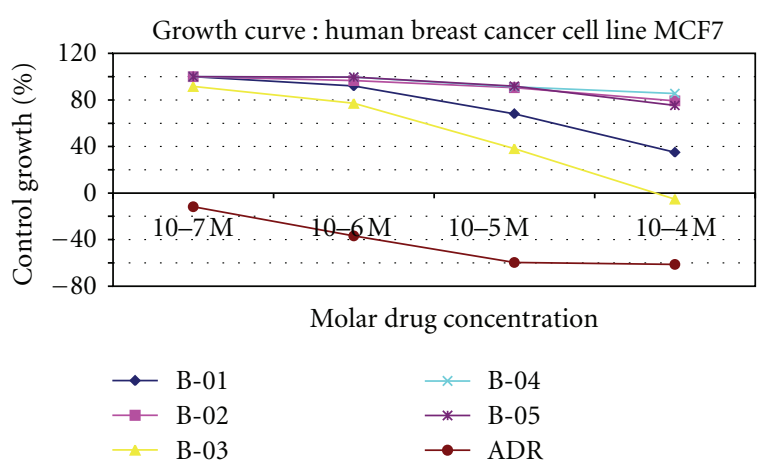

(b)

FIgure 1: Invitro cytotoxic effects of DHPM's against two Human Cancer Cell Lines.

PPA acts as better promoter as compared to lithium-acetate. The use of solvent-free conditions, short reaction times, excellent yields, easy workup, and compatibility with various functional groups makes the present catalytic reaction an environmentally acceptable method for the synthesis of dihydropyrimidinones and thiones.

\section{Experimental}

4.1. Chemical Analysis. Reagents and solvents were obtained from commercial sources and used without further purification. Melting points were determined on a Toshniwal apparatus. The spectral analyses of synthesized compounds have been carried out at SAIF, Punjab University, Chandigarh. Purity of all compounds was checked by TLC using "G-" coated glass plates and benzene: ethyl acetate $(9: 1)$, benzene: ethyl acetate: methanol $(8.5: 1.4: 0.1)$ as eluent. IR spectra were recorded in $\mathrm{KBr}$ on a Perkin Elmer Infrared RXI FTIR spectrophotometer and ${ }^{1} \mathrm{H}$ NMR spectra were recorded on Bruker Avance II 400 NMR Spectrometer using DMSO$\mathrm{d}_{6}$ and $\mathrm{CDCl}_{3}$ as solvent and tetramethylsilane (TMS) as internal reference standard. The room temperature means $30-40^{\circ} \mathrm{C}$. The obtained products were identified by comparison with authentic samples (synthesized by conventional process) and from their spectral ( ${ }^{1} \mathrm{H}$ NMR and IR) data and the melting points were confirmed by comparison with those reported in the literature.

4.2. Experimental Procedure for the Synthesis of Dihydropyrimidinones Using Solvents (Table 1). For comparison sake, compound 1 was synthesized by stirring at room temperature in various solvents, for example, ethanol, toluene, water, and acetonitrile for 7-8 hrs using both lithium-acetate and polyphosphoric acid as catalysts. A mixture of an aromatic aldehyde $(1 \mathrm{mmol}), \beta$-dicarbonyl compound $(1 \mathrm{mmol})$, urea/thiourea $(2 \mathrm{mmol}), \mathrm{PPA} /$ lithium-acetate $(0.5 \mathrm{mmol})$, and solvent $(5 \mathrm{~mL})$ was mixed in R.B. flask and the mixture was magnetically stirred at room temperature for the time needed to complete the reaction (as monitored by TLC). After completion, the reaction mixture was cooled to room temperature and poured onto crushed ice, filtered, and recrystallized by using either ethanol or ethyl acetate and pet ether $(1: 1)$ to afford pure product. Results are summarized in Table 1.

\subsection{General Procedure for the Synthesis of Dihydropyrimidinones}

Method I. A mixture of an aromatic aldehyde $(1 \mathrm{mmol})$, $\beta$-dicarbonyl compound $(1 \mathrm{mmol})$, urea/thiourea $(2 \mathrm{mmol})$ $\mathrm{PPA} /$ lithium-acetate $(0.5 \mathrm{mmol})$ was mixed in R.B. flask and the mixture was magnetically stirred at $70-80^{\circ} \mathrm{C}$ for the time needed to complete the reaction (as monitored by TLC). The initial syrupy reaction mixture solidifies within 30-35 minutes. After completion, the reaction mixture was cooled to room temperature and poured onto crushed ice, filtered, and recrystallized by using either ethanol or ethyl acetate and pet ether $(1: 1)$ to afford pure product. The obtained products were identified from their spectral $\left({ }^{1} \mathrm{H}\right.$ NMR and IR) data and their literature melting points.

Method II. A mixture of an aromatic aldehyde ( $1 \mathrm{mmol})$, $\beta$-dicarbonyl compound $(1 \mathrm{mmol})$, urea/thiourea $(2 \mathrm{mmol})$, and PPA/lithium-acetate $(0.5 \mathrm{mmol})$ was ground together for 5-10 min. using a mortar and pestle of appropriate size. The initial syrupy reaction mixture solidifies within 15-20 minutes. The solid mass was left overnight, then washed with cold water, and purified either by recrystallization from ethyl acetate and pet ether $(1: 1)$ or by column chromatography of resulting crude material over silica gel using ethyl acetate and pet ether $(1.5: 8.5)$ as the mobile phase. All the compounds given in Table 2 are synthesized by both the methods and it has been observed that yields of the synthesized compounds obtained by Method I is $10-15 \%$ better than that obtained by Method II. below.

Spectral data of newly synthesized compounds are given

Compound 13 Ethyl-6-methyl-2-thioxo-4-(3-methoxyphenyl)1,2,3,4-tetrahydropyrimidin-5-carboxylate. IR ( $\mathrm{KBr}$ ): 3235, 3120, 2930, 2823, 1672, 1573, 1467, 1282, 1190, 1125, 723, $692 \mathrm{~cm}^{-1} ;{ }^{1} \mathrm{H}$ NMR (DMSO-d $): 1.12\left(\mathrm{t}, 3 \mathrm{H}, \mathrm{OCH}_{2} \mathrm{CH}_{3}\right)$, $2.26\left(\mathrm{~s}, 3 \mathrm{H}, 6-\mathrm{CH}_{3}\right), 3.77\left(\mathrm{~s}, 3 \mathrm{H}, \mathrm{OCH}_{3}\right), 4.01(\mathrm{q}, 2 \mathrm{H}$, 
$\left.\mathrm{OCH}_{2} \mathrm{CH}_{3}\right), 5.12$ (s, 1H, CH), 6.58-7.03 (m, 4H, aromatic), $7.63(\mathrm{~s}, 1 \mathrm{H}, \mathrm{N}-\mathrm{H}), 9.45(\mathrm{~s}, 1 \mathrm{H}, \mathrm{N}-\mathrm{H})$ ppm. Analytical Calculation for $\mathrm{C}_{15} \mathrm{H}_{18} \mathrm{~N}_{2} \mathrm{O}_{3} \mathrm{~S}$ : C, 58.80; H, 5.92; N, 9.14. Found: C, 58.62; H, 5.90; N, 9.17.

Compound 14 Ethyl-6-methyl-2-oxo-4-(2,4-dimethylphenyl)1,2,3,4-tetrahydropyrimidin-5-carboxylate. IR ( $\mathrm{KBr})$ : 3234, $3110,2933,2833,1703,1649,1511,1455,1276,1175$, $791 \mathrm{~cm}^{-1} ;{ }^{1} \mathrm{H}$ NMR (DMSO-d 6 ): $1.12\left(\mathrm{t}, 3 \mathrm{H}, \mathrm{OCH}_{2} \mathrm{CH}_{3}\right.$ ), $2.27\left(\mathrm{~s}, 3 \mathrm{H}, 6-\mathrm{CH}_{3}\right), 2.35\left(\mathrm{~s}, 3 \mathrm{H}, 2-\mathrm{CH}_{3}\right), 2.35(\mathrm{~s}, 3 \mathrm{H}, 4-$ $\left.\mathrm{CH}_{3}\right), 4.02\left(\mathrm{q}, 2 \mathrm{H}, \mathrm{OCH}_{2} \mathrm{CH}_{3}\right), 5.11(\mathrm{~s}, 1 \mathrm{H}, \mathrm{CH}), 6.74-6.82$ (m, 3H, aromatic), $7.61(\mathrm{~s}, 1 \mathrm{H}, \mathrm{N}-\mathrm{H}), 9.47(\mathrm{~s}, 1 \mathrm{H}, \mathrm{N}-\mathrm{H})$ ppm. Analytical Calculation for $\mathrm{C}_{16} \mathrm{H}_{20} \mathrm{~N}_{2} \mathrm{O}_{3}$ : C, 66.65; $\mathrm{H}$, 6.99; N, 9.72. Found: C, 66.46; H, 6.97; N, 9.75.

Compound 15 Ethyl-6-methyl-2-thioxo-4-(3,4-dimethylphenyl)-1,2,3,4-tetrahydropyrimidin-5-carboxylate. IR ( $\mathrm{KBr})$ : 3313, 3171, 2989, 2842, 1668, 1575, 1460, 1373, 1332, 1259, 1192, $1118,769 \mathrm{~cm}^{-1} ;{ }^{1} \mathrm{H}$ NMR (DMSO-d 6$): 1.11(\mathrm{t}, 3 \mathrm{H}$, $\left.\mathrm{OCH}_{2} \mathrm{CH}_{3}\right), 2.28\left(\mathrm{~s}, 3 \mathrm{H}, 6-\mathrm{CH}_{3}\right), 2.32\left(\mathrm{~s}, 3 \mathrm{H}, 3-\mathrm{CH}_{3}\right), 2.33$ $\left(\mathrm{s}, 3 \mathrm{H}, 4-\mathrm{CH}_{3}\right), 4.05$ (q, $\left.2 \mathrm{H}, \mathrm{OCH}_{2} \mathrm{CH}_{3}\right), 5.10(\mathrm{~s}, 1 \mathrm{H}, \mathrm{CH})$, 6.72-6.81 (m, 3H, aromatic), $7.64(\mathrm{~s}, 1 \mathrm{H}, \mathrm{N}-\mathrm{H}), 9.43$ (s, $1 \mathrm{H}, \mathrm{N}-\mathrm{H}$ ) ppm. Analytical Calculation for $\mathrm{C}_{16} \mathrm{H}_{20} \mathrm{~N}_{2} \mathrm{O}_{2} \mathrm{~S}: \mathrm{C}$, 63.13; H, 6.62; N, 9.20. Found: C, 63.24; H, 6.64; N, 9.17.

Compound 19 Methyl-6-methyl-2-thioxo-4-(3,4,5-trimethoxyphenyl)-1,2,3,4-tetrahydropyrimidine-5-carboxylate. IR (KBr): 3213, 3172, 3110, 2882, 1660, 1570, 1511, 1456, 1372, 1320, 1250, 1177, 1115, $765 \mathrm{~cm}^{-1} ;{ }^{1} \mathrm{H}$ NMR (DMSO-d 6 ): $2.36\left(\mathrm{~s}, 3 \mathrm{H}, \mathrm{OCH}_{3}\right), 2.13\left(\mathrm{~s}, 3 \mathrm{H}, 6-\mathrm{CH}_{3}\right), 3.81-4.22(\mathrm{~s}, 9 \mathrm{H}$, Ar- $\mathrm{OCH}_{3}$ ), 5.12 (s, 1H, CH), 6.11-6.23 (d, 2H, aromatic), $7.76(\mathrm{~s}, 1 \mathrm{H}, \mathrm{N}-\mathrm{H}), 9.42(\mathrm{~s}, 1 \mathrm{H}, \mathrm{N}-\mathrm{H})$ ppm. Analytical Calculation for $\mathrm{C}_{16} \mathrm{H}_{20} \mathrm{~N}_{2} \mathrm{O}_{5} \mathrm{~S}$ : C, 54.53; H, 5.72; N, 7.95. Found: C, 54.42; H, 5.71; N, 7.98.

Compound 20 Methyl 6-methyl-2-oxo-4-(3,4,5-trimethoxyphenyl)-1,2,3,4-tetrahydropyrimidine-5-carboxylate. IR (KBr): 3215, 3170, 3120, 2880, 1702, 1670, 1578, 1511, 1465, 1320, 1280, 1177, 1030, $762 \mathrm{~cm}^{-1} ;{ }^{1} \mathrm{H}$ NMR (DMSO-d 6 ): $2.32\left(\mathrm{~s}, 3 \mathrm{H}, \mathrm{OCH}_{3}\right), 2.11\left(\mathrm{~s}, 3 \mathrm{H}, 6-\mathrm{CH}_{3}\right), 3.67-4.32(\mathrm{~s}, 9 \mathrm{H}$, Ar- $\left.\mathrm{OCH}_{3}\right), 5.13$ (s, 1H, CH), 6.12-6.25 (d, 2H, aromatic), $7.82(\mathrm{~s}, 1 \mathrm{H}, \mathrm{N}-\mathrm{H}), 9.43(\mathrm{~s}, 1 \mathrm{H}, \mathrm{N}-\mathrm{H})$ ppm. Analytical Calculation for $\mathrm{C}_{16} \mathrm{H}_{20} \mathrm{~N}_{2} \mathrm{O}_{6}: \mathrm{C}, 57.14 ; \mathrm{H}, 5.99 ; \mathrm{N}, 8.33$ Found: C, 57.34; H, 5.97; N, 8.35.

Compound 22 Ethyl 6-methyl-2-oxo-4-(4-(trifluoromethyl)phenyl)-1,2,3,4-tetrahydropyrimidine-5-carboxylate. IR (KBr): 3244, 3122, 3109, 1720, 1690, 1571, 1460, 1312, 1270, 1077, $783 \mathrm{~cm}^{-1} ;{ }^{1} \mathrm{H}$ NMR (DMSO-d 6$): 1.10(\mathrm{t}, 3 \mathrm{H}$, $\left.\mathrm{OCH}_{2} \mathrm{CH}_{3}\right), 2.23\left(\mathrm{~s}, 3 \mathrm{H}, 6-\mathrm{CH}_{3}\right), 3.99$ (q, $\left.2 \mathrm{H}, \mathrm{OCH}_{2} \mathrm{CH}_{3}\right)$, 5.09 (s, 1H, CH), 6.18-6.27 (m, 4H, aromatic), $7.60(\mathrm{~s}, 1 \mathrm{H}$, $\mathrm{N}-\mathrm{H}), 9.39$ (s, 1H, N-H) ppm. Analytical Calculation for $\mathrm{C}_{15} \mathrm{H}_{15} \mathrm{~F}_{3} \mathrm{~N}_{2} \mathrm{O}_{3}$ : C, 54.88; H, 4.61; N, 8.53. Found: C, 54.68; $\mathrm{H}, 4.59 ; \mathrm{N}, 8.56$.

Compound 23 Ethyl 6-methyl-2-oxo-4-(2-(trifluoromethyl)phenyl)-1,2,3,4-tetrahydropyrimidine-5-carboxylate. IR (KBr): 3240, 3124, 3103, 1718, 1683, 1572, 1466, 1309,
1266, 1037, $769 \mathrm{~cm}^{-1} ;{ }^{1} \mathrm{H}$ NMR (DMSO-d 6$): 1.10(\mathrm{t}, 3 \mathrm{H}$, $\left.\mathrm{OCH}_{2} \mathrm{CH}_{3}\right), 2.21\left(\mathrm{~s}, 3 \mathrm{H}, 6-\mathrm{CH}_{3}\right), 3.98\left(\mathrm{q}, 2 \mathrm{H}, \mathrm{OCH}_{2} \mathrm{CH}_{3}\right)$, $5.02(\mathrm{~s}, 1 \mathrm{H}, \mathrm{CH}), 6.17-6.25(\mathrm{~m}, 4 \mathrm{H}$, aromatic), $7.62(\mathrm{~s}, 1 \mathrm{H}$, $\mathrm{N}-\mathrm{H}), 9.37$ (s, 1H, N-H) ppm. Analytical Calculation for $\mathrm{C}_{15} \mathrm{H}_{15} \mathrm{~F}_{3} \mathrm{~N}_{2} \mathrm{O}_{3}$ : C, 54.88; H, 4.61; N, 8.53. Found: C, 54.70; $\mathrm{H}, 4.59 ; \mathrm{N}, 8.55$.

Compound 24 1-Acetyl-6-(3-hydroxy-4-methoxyphenyl)-4methyl-2-thioxo-1,2,3,6-tetrahydropyrimidine-5-carbonyl cyanide. IR (KBr): 3251, 3432, 2225, 1728, 1381, 1250, $1115 \mathrm{~cm}^{-1}$; ${ }^{1} \mathrm{H}$ NMR (DMSO): 2.00 (s, 1H, NH), 2.02 (s, $3 \mathrm{H}, \mathrm{COCH}_{3}$ ), 2.27 (s, 3H, 4- $\mathrm{CH}_{3}$ ), 3.73 (s, 3H, Ar- $\mathrm{OCH}_{3}$ ), 5.56 (s, 1H, cyclic CH), 6.23 (s, 1H, Ar-H), 6.23-7.10 (d, 2H, Ar-H), 9.83 (s, 1H, ArOH) ppm. Analytical Calculation for $\mathrm{C}_{16} \mathrm{H}_{15} \mathrm{~N}_{3} \mathrm{O}_{4} \mathrm{~S}$ : C, 55.64; H, 4.38; N, 12.17. Found: C, 55.55; $\mathrm{H}, 4.40 ; \mathrm{N}, 12.20$.

Compound 25. 1-Acetyl-6-(4-hydroxy-3-methoxyphenyl)4-methyl-2-thioxo-1,2,3,6-tetrahydropyrimidine-5-carbonyl cyanide. IR (KBr): 3254, 3435, 2233, 1722, 1382, $1240 \mathrm{~cm}^{-1}$; ${ }^{1} \mathrm{H}$ NMR (DMSO): 2.20 (s, 1H, NH), 2.23 (s, 3H, $\mathrm{COCH}_{3}$ ), $2.27\left(\mathrm{~s}, 3 \mathrm{H}, 4-\mathrm{CH}_{3}\right), 3.77\left(\mathrm{~s}, 3 \mathrm{H}, \mathrm{OCH}_{3}\right), 5.57$ (s, $1 \mathrm{H}$, cyclic $\mathrm{CH}), 6.38-7.22$ (m, 3H, Ar-H), 9.81 (s, 1H, ArOH) ppm. Analytical Calculation for $\mathrm{C}_{16} \mathrm{H}_{15} \mathrm{~N}_{3} \mathrm{O}_{4} \mathrm{~S}$ : C, 55.64; $\mathrm{H}, 4.38$; N, 12.17. Found: C, 55.40; H, 4.36; N, 12.14 .

Compound 26 1-Acetyl-6-(4-hydroxyphenyl)-4-methyl-2thioxo-1,2,3,6-tetrahydropyrimidine-5-carbonyl cyanide. IR (KBr): 3252, 3433, 2235, 1725, 1383, 1251, $1121 \mathrm{~cm}^{-1} ;{ }^{1} \mathrm{H}$ NMR (DMSO): 2.40 (s, 1H, NH), 2.05 (s, 3H, $\left.\mathrm{COCH}_{3}\right), 2.27$ $\left(\mathrm{s}, 3 \mathrm{H}, 4-\mathrm{CH}_{3}\right), 5.58(\mathrm{~s}, 1 \mathrm{H}$, cyclic $\mathrm{CH}), 6.23-7.10(\mathrm{~m}, 4 \mathrm{H}$, Ar-H), 9.88 (s, 1H, ArOH) ppm. Analytical Calculation for $\mathrm{C}_{15} \mathrm{H}_{13} \mathrm{~N}_{3} \mathrm{O}_{3} \mathrm{~S}$ : C, 57.13; H, 4.16; N, 13.33. Found: C, 56.95; $\mathrm{H}, 4.15 ; \mathrm{N}, 13.35$.

Compound 27 1-Acetyl-6-(4-chlorophenyl)-4-methyl-2thioxo-1,2,3,6-tetrahydropyrimidine-5-carbonyl cyanide. IR (KBr): 3255, 2735, 2231, 1721, 1380, $1242 \mathrm{~cm}^{-1} ;{ }^{1} \mathrm{H}$ NMR (DMSO): 2.27 (s, 3H, 4- $\left.\mathrm{CH}_{3}\right), 2.40$ (s, 1H, NH), 2.21 (s, 3H, $\left.\mathrm{COCH}_{3}\right), 5.55$ (s, $1 \mathrm{H}$, cyclic $\left.\mathrm{CH}\right), 6.38-7.22(\mathrm{~m}, 4 \mathrm{H}, \mathrm{Ar}-\mathrm{H})$ ppm. Analytical Calculation for $\mathrm{C}_{15} \mathrm{H}_{12} \mathrm{ClN}_{3} \mathrm{O}_{2} \mathrm{~S}$ : C, 53.97; H, 3.62; N, 12.59. Found: C, 53.72; H, 3.64; N, 12.56 .

\section{Acknowledgments}

The authors are thankful to the Dean, Professor P. K. Das and to the Head of the Department, Professor K. Singh (Science and Humanities), FET, MITS, for providing necessary research facilities in the department. Financial assistance from FET, MITS is gratefully acknowledged. They are also thankful to ACTREC, TATA Memorial Centre for Anticancer Screening, and SAIF Punjab University, Chandigarh for the spectral and elemental analyses.

\section{References}

[1] S. Achatz and A. Dömling, "Desosamine in multicomponent reactions," Bioorganic and Medicinal Chemistry Letters, vol. 16, no. 24, pp. 6360-6362, 2006. 
[2] W. S. Bremner and M. G. Organ, "Multicomponent reactions to form heterocycles by microwave-assisted continuous flow organic synthesis," Journal of Combinatorial Chemistry, vol. 9, no. 1, pp. 14-16, 2007.

[3] P. Biginelli, "Synthesis of dihydropyrimidinones," Gazzetta Chimica Italiana, vol. 23, pp. 360-416, 1893.

[4] M. A. AbdulKarim, Al-Kadasi, and G. M. J. Nazeruddin, "An ultrasonic assisted multicomponent reaction for the synthesis of 3, 4-dihydropyrimidin-2(1H)-ones under solvent-free condition," Journal of Chemical and Pharmaceutical Research, vol. 2, no. 3, pp. 536-543, 2010.

[5] F. Toda, K. Tanaka, and A. Sekikawa, "Host-guest complex formation by a solid-solid reaction," Journal of the Chemical Society, Chemical Communications, no. 4, pp. 279-280, 1987.

[6] A. K. Bose, S. Pednekar, S. N. Ganguly, G. Chakraborty, and M. S. Manhas, "A simplified green chemistry approach to the Biginelli reaction using "Grindstone Chemistry"," Tetrahedron Letters, vol. 45, no. 45, pp. 8351-8353, 2004.

[7] G. Nagendrappa, "Organic synthesis under solvent-free condition: an environmentally benign procedure-I," Resonance, vol. 7, no. 10, pp. 59-68, 2002.

[8] G. Rothenberg, A. P. Downie, C. L. Raston, and J. L. Scott, "Understanding solid/solid organic reactions," Journal of the American Chemical Society, vol. 123, no. 36, pp. 8701-8708, 2001.

[9] B. C. Ranu, S. S. Dey, and S. Samanta, "Indium(III) chloridecatalyzed Michael addition of thiols to chalcones: a remarkable solvent effect," Arkivoc, vol. 2005, no. 3, pp. 44-50, 2004.

[10] P. P. Baruah, S. Gadhwal, D. Prajapati, and J. S. Sandhu, "The Biginelli condensation: a novel and efficient regioselective synthesis of dihydropyrimidin-2(1H)-ones using lithium bromide," Chemistry Letters, no. 10, pp. 1038-1039, 2002.

[11] Y. Zhu, Y. Pan, and S. Huang, "Trimethylsilyl chloride: a facile and efficient reagent for one-pot synthesis of 3,4dihydropyrimidin-2(1H)-ones," Synthetic Communications, vol. 34, no. 17, pp. 3167-3174, 2004.

[12] J. Lu, Y. Bai, Z. Wang, B. Yang, and H. Ma, "One-pot synthesis of 3,4-dihydropyrimidin-2(1H)-ones using lanthanum chloride as a catalyst," Tetrahedron Letters, vol. 41, no. 47, pp. 9075-9078, 2000.

[13] D. S. Bose, L. Fatima, and H. B. Mereyala, "Green chemistry approaches to the synthesis of 5-alkoxycarbonyl-4aryl-3,4-dihydropyrimidin-2(1H)-ones by a three-component coupling of one-pot condensation reaction: comparison of ethanol, water, and solvent-free conditions," Journal of Organic Chemistry, vol. 68, no. 2, pp. 587-590, 2003.

[14] K. Kumar, M. Kasthuraiah, C. Suresh Reddy, and C. Devendranath Reddy, " $\mathrm{Mn}(\mathrm{OAc}) 3 \cdot 2 \mathrm{H}_{2} \mathrm{O}$-mediated threecomponent, one-pot, condensation reaction: an efficient synthesis of 4-aryl-substituted 3,4-dihydropyrimidin-2-ones," Tetrahedron Letters, vol. 42, no. 44, pp. 7873-7875, 2001.

[15] M .A. P. Martins, M. V. M. Teixeira, W. Cunico et al., "Indium (III) bromide catalyzed one-pot synthesis of trichloromethylated tetrahydropyrimidinones," Tetrahedron Letters, vol. 45, no. 49, pp. 8991-8994, 2004.

[16] I. S. Zorkun, S. Saraç, S. Çelebi, and K. Erol, "Synthesis of 4-aryl-3,4-dihydropyrimidin-2(1H)-thione derivatives as potential calcium channel blockers," Bioorganic and Medicinal Chemistry, vol. 14, no. 24, pp. 8582-8589, 2006.

[17] M. M. Sanchez Duque, C. Allais, N. Isambert, T. Constantieux, and J. Rodriguez, "Beta-diketo building blocks for MCRsbased syntheses of heterocycles," Topics in Heterocyclic Chemistry, vol. 23, pp. 227-277, 2010.

[18] K. V. N. S. Srinivas and B. Das, "Iodine catalyzed one-pot synthesis of 3,4-dihydropyrimidin-2(1H)-ones and thiones: a simple and efficient procedure for the Biginelli reaction," Synthesis, no. 13, pp. 2091-2093, 2004.

[19] M. A. Pasha, N. R. Swamy, and V. P. Jayashankara, "Onepot synthesis of 3,4-dihydropyrimidin-2(1H)-ones/-thiones catalyzed by zinc chloride: an improved procedure for the Biginelli reaction using microwaves under solvent-free condition," ChemInform, vol. 36, no. 34, 2005.

[20] J. Lu, Y. J. Bai, Y. H. Guo, Z. J. Wang, and H. R. Ma, " $\mathrm{CoCl}_{2} \cdot 6 \mathrm{H}_{2} \mathrm{O}$ or $\mathrm{LaCl}_{3} \cdot 7 \mathrm{H}_{2} \mathrm{O}$ catalyzed biginelli reaction. One-pot synthesis of 3,4-dihydropyrimidin-2(1H)-ones," Chinese Journal of Chemistry, vol. 20, no. 7, pp. 681-687, 2002.

[21] A. Karamat, M. A. Khan, and A. Sharif, "Metal acetate mediated Biginelli one-pot synthesis," Journal of the Chinese Chemical Society, vol. 57, no. 5, pp. 1099-1101, 2010.

[22] A. Dandia, R. Singh, H. Sachdeva, and K. Arya, "Microwave assisted one pot synthesis of a series of trifluoromethyl substituted spiro [indole-triazoles]," Journal of Fluorine Chemistry, vol. 111, no. 1, pp. 61-67, 2001.

[23] A. Dandia, H. Sachdeva, and R. Singh, "Improved synthesis of 3-spiro indolines in dry media under microwave irradiation," Synthetic Communications, vol. 31, no. 12, pp. 1879-1892, 2001.

[24] V. N. Pathak, R. Gupta, and B. Varshney, "An efficient, inexpensive 'Green Chemistry' route to multicomponent Biginelli condensation catalyzed by $\mathrm{CuCl}_{2} \cdot 2 \mathrm{H}_{2} \mathrm{O}-\mathrm{HCl}$," Indian Journal of Chemistry Section B, vol. 47, no. 3, pp. 434-438, 2008.

[25] B. Boumoud, T. Boumoud, A. Belfaitah, S. Rhouati, B. Carboni, and A. Debache, "A convenient one-step synthesis of 3,4-dihydropyrimidin-2(1H)-ones by nickel (II) nitrate hexahydrate catalyzed Biginelli reaction," Journal de la Société Algérienne de Chimie, vol. 19, no. 1, pp. 63-71, 2009.

[26] N. Y. Fu, Y. F. Yuan, Z. Cao, S. W. Wang, J. T. Wang, and C. Peppe, "Indium(III) bromide-catalyzed preparation of dihydropyrimidinones: improved protocol conditions for the Biginelli reaction," Tetrahedron, vol. 58, no. 24, pp. 4801-4807, 2002.

[27] B. B. F. Mirjalili, A. Bamoniri, and A. Akbari, "Synthesis of 14-aryl or alkyl-14H-dibenzo[a,j]xanthenes promoted by $\mathrm{Mg}\left(\mathrm{HSO}_{4}\right)_{2}$," Chinese Chemical Letters, vol. 22, no. 1, pp. 4548, 2011.

[28] N. Rameshwar, T. Parthasarathy, and A. RamReddy, "Tin(IV) catalyzed one-pot synthesis of 3,4-dihydropyrimidin-2-(1H)ones under solvent-free conditions," Indian Journal of Chemistry Section B, vol. 47, no. 12, pp. 1871-1875, 2008.

[29] F. L. Zumpe, M. Flu, K. Schmitz, and A. Lender, "Propane phosphonic acid anhydride: a new promoter for the onepot Biginelli synthesis of 3,4-dihydropyrimidin-2(1H)-ones," Tetrahedron Letters, vol. 48, no. 8, pp. 1421-1423, 2007.

[30] R. Ghosh, S. Maiti, and A. Chakraborty, "In(OTf)3-catalysed one-pot synthesis of 3,4-dihydropyrimidin- 2(1H)-ones," Journal of Molecular Catalysis A, vol. 217, no. 1-2, pp. 47-50, 2004.

[31] V. Vichai and K. Kirtikara, "Sulforhodamine B colorimetric assay for cytotoxicity screening," Nature Protocols, vol. 1, no. 3, pp. 1112-1116, 2006. 

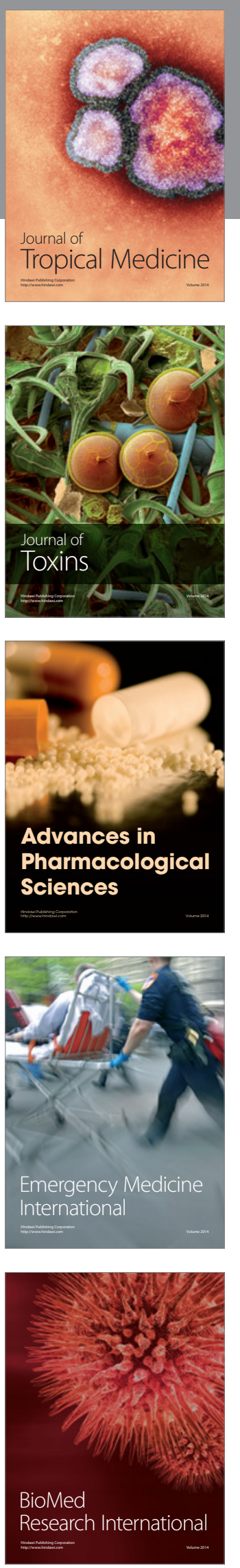
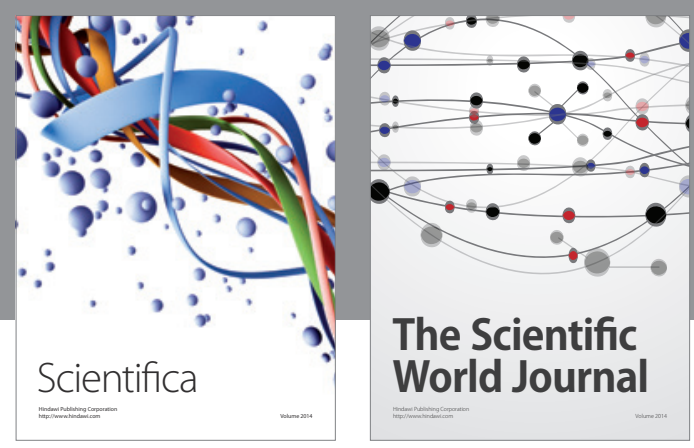

The Scientific World Journal
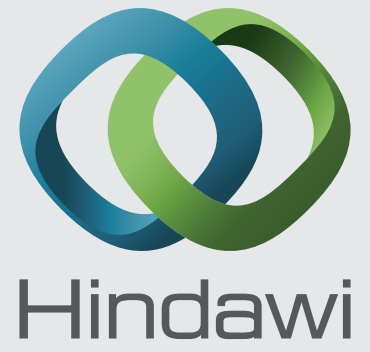

Submit your manuscripts at

http://www.hindawi.com
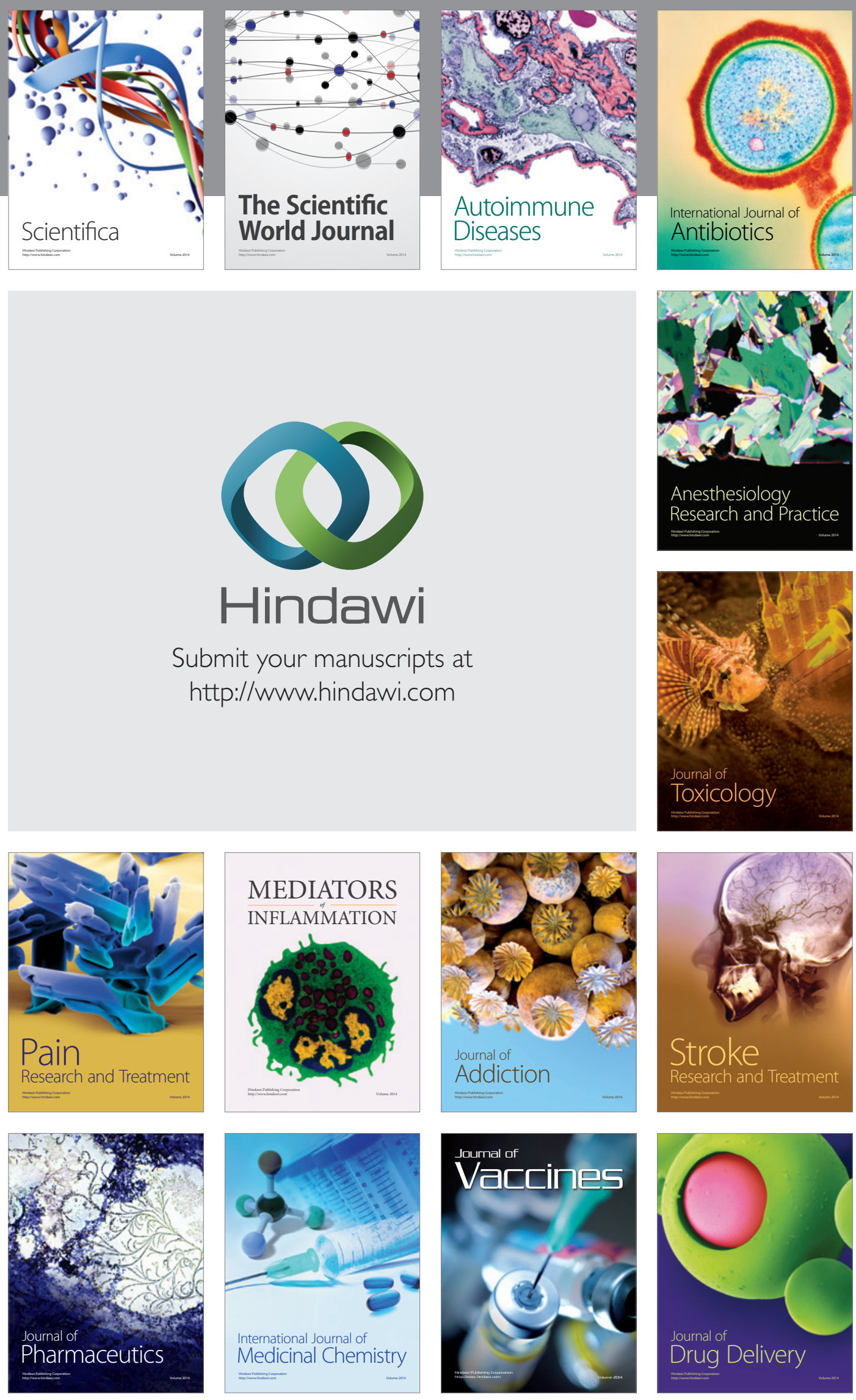